\title{
Hypsometric Properties of South Zagros Fold-Thrust Belt Basins: A Case Study in Namdan Basin in SW Iran
}

\author{
Asma Nikoonejad1, Mohsen Pourkermani1 ${ }^{*}$, Abdoolmajid Asadi' ${ }^{2}$ Mahmud Almasian1 \\ ${ }^{1}$ Department of Geology, College of Basic Sciences, North Tehran Branch, \\ Islamic Azad University, Tehran, Iran \\ ${ }^{2}$ Department of Geology, College of Basic Sciences, Shiraz Branch, Islamic Azad University, Shiraz, Iran \\ Email: ${ }^{*}$ mohsen.poukermani@gmail.com
}

Received 11 August 2015; accepted 25 October 2015; published 29 October 2015

Copyright (c) 2015 by authors and Scientific Research Publishing Inc.

This work is licensed under the Creative Commons Attribution International License (CC BY). http://creativecommons.org/licenses/by/4.0/

(c)

\section{Abstract}

Study area is located in Southwest Iran with relatively flat topography. Outcropped lithological units in the region belong from Triassic and Jurassic till recent era. The study area of the Namdan basin is related to the tectonic zone of the high Zagros region and the compressional-extensional regime. Geomorphic indices of active tectonics are useful tools to analyze the influence of activity. One of them is hypsometric integral which has generally been used to reveal the stages of geomorphic development. It is estimated by the graphical plot of the measured contour elevation and encompassed area by using empirical formulae. In constructing the hypsometric integral curve, a Digital Elevation Model (DEM) with $30 \mathrm{~m}$ spatial resolution has been used. This index is calculated in the study area. Then, based on index of its values, the hypsometric properties of drainage basins are analyzed in Namdan basin. Three different approaches were used for estimation of hypsometric integrals. The hypsometric integral values (HI) range between 0.18 and 0.31 for all the basins of study basin. In the study area, one stage of erosion cycle development, namely old stage is distinguished. Our results indicate that there is anomaly in Hi value which is located on faulted area. The results indicate the Northwest of Namdan basin and a small part of its Southeast are more active than other ones.

\section{Keywords}

Active Tectonics, Eqlid, Hypsometric Integral, Index, Iran Namdan

\footnotetext{
${ }^{*}$ Corresponding author.
}

How to cite this paper: Nikoonejad, A., Pourkermani, M., Asadi, A. and Almasian, M. (2015) Hypsometric Properties of South Zagros Fold-Thrust Belt Basins: A Case Study in Namdan Basin in SW Iran. Open Journal of Geology, 5, 701-717. 


\section{Introduction}

Tectonic geomorphology is inflexible competition between tectonic and surface processes [1]. In fact, evaluation of structures and landforms during history genesis of them is a subject for tectonics and geomorphology [2]. Investigation of the geomorphic record provides the basic data necessary to understand the role of active tectonics in the development of a site or an area.

Morphometry is becoming a unique part of structurally geomorphologic studies after W. B. Bull and L. D. McFadden (1977) and it develops with the introduction of DEM and GIS technologies [3].

Geographic information system (GIS) is used in different branches of earth science such as providing geomorphology, hazard, zoning and mineral potential maps. The most important objective of geographic information system is the integration of spatial data and their final assessment. The GIS has display facilities and analysis of data concurrently which make it possible for geologist to work with many geological data in more speed and accuracy. It should be mentioned that it is impossible in analog and tradition methods [4].

Each one of geomorphology indices represents a relative classification for quantity of tectonically activities. There is a huge progress in development of quantitative hypsometry. Vast research is carried out in studying the hypsometry index [5]-[8].

In this study, we tried to measure the required parameters using Digital Elevation Model with 30 meter resolution at ARC GIS software. In order to identify the hypsometry anomalies, we use climate, rock strength level, geomagnetic and structural maps. In fact, the purpose of this study is to use the procedure and the information of geology and climatology to understand the hypsometry properties of Namdan basin.

Iran is a part of the Alpine-Himalayan orogenic belt that represents the great Tethys Sea once located between two large continents, Gondwana and Laurasia, during Paleozoic-Mesozoic eras. Many geologists have studied structural history and tectonics for Iran [9] [10]. They show that there are many different structural units, for example Berberian [9] who divides Iran into four major structural-geological units separable on the basis of regional difference in structural-geological characteristics which are included: Zagros active folded belt [11] [12], Central Iran, KopehDagh ranges and Alborz Mountains (from Bandar Pahlavi to Gorgan). Last zoning map of Iran based on Physiographic-tectonic of sedimentary basins has been prepared by Arian [13] (Figure 1). Iran has divided into four continental unites consist of, Cimmerian miniplate at least can be divided to the smaller part, East-Central Iran and North-Central Iran microcontinents, Eurasian and Arabian continents. East Alborzhinterland is the oldest orogenic belt and Zagros hinterland is the newest orogenic beltof Iran [13]. Zagros zone extends from Bandar Abbas in the south to Kermanshah in the northwest and continues through to Iraq. It is in fact the northeastern edge of the Arabian plate.

The study area is about 304,000 hectare in the terminal zone of the high Zagros belt in Fars Province, southwest Iran. Major rock groups are Bakhtiari, Asmari, Jahrom, Fahliyan, Daryan, Khanehkat, and Neyriz (Figure 2). Central point of Namdan basin is located at longitudes $52^{\circ} 42^{\prime} \mathrm{E}$ and latitude $30^{\circ} 55^{\prime} \mathrm{N}$. Average altitude of it is various from 3370 meter at Mountains to 2200 meter at low terrains from open seas level.

The annual temperature average of this region is 7.5 varying from $37^{\circ} \mathrm{C}$ to $-22^{\circ} \mathrm{C}$ from winter to summer. The annual average precipitation of this region is $32 \%$ to $43 \%$. The regional climate according to Do martin method is semi-aired cold [14]. The average rainfall of Namdanbasin is 300 to 600 millimeter. The climate of the region is characterized by a hot summer and well distributed seasonal rainfall. The Shadkam River is the most important river of this watershed which takes its origin in Shadkam spring at Almaijeh Mountain.

The Kaftar Lake is the one of fresh water lakes in Iranian plateau which has been located in the easternmost part of Namdanbasin. This lake (with area approximately 7500 acres) is 2300 meters high above sea level and is $24 \mathrm{~km}$ long and $6 \mathrm{~km}$ wide [15].

\section{Materials and Methods}

In the field of tectonics geomorphology and landscape evolution, the use of GIS is relatively recent. The availability of the DEM has produced a great revolution in this field. It has replaced old topographic maps, allowing for better and faster analysis of topographic parameters. One of the most important features of DEM is the possibility of extracting river networks with stream gradients and catchments areas [16].

Geographical information system has been used for data preparation, data manipulation and analysis of data. ARCGIS 9.3 has been used for the present study. The Digital Elevation Model (DEM) with $30 \mathrm{~m}$ spatial resolu- 


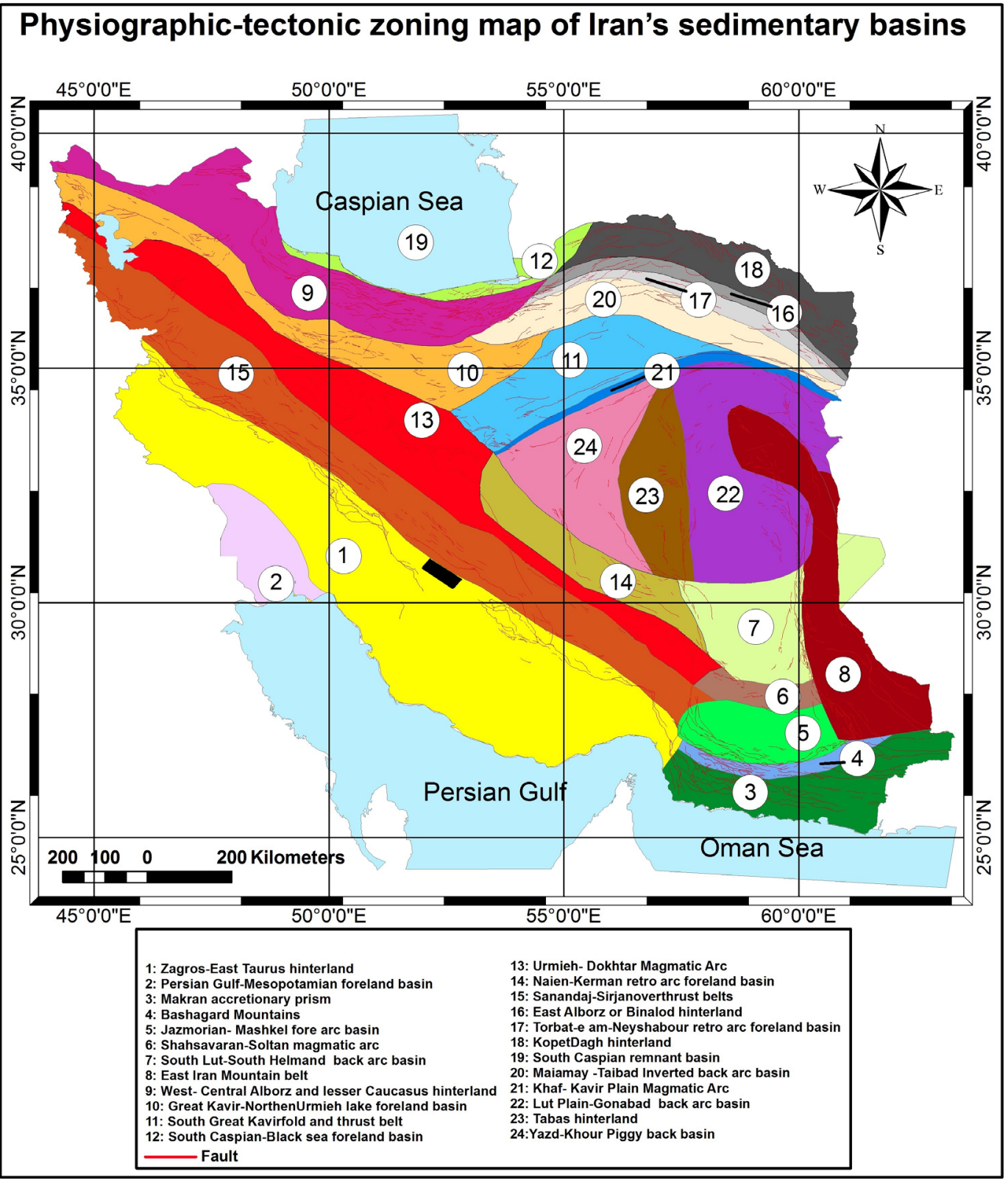

Figure 1. Physiographic-tectonic zoning map of Iran's sedimentary basins Iran modified from [1]. The study area is shown in the black rectangle.

tion has been used as a base map. The drainage basin's boundary has been identified through an extension called arc hydro tools 9 (fill, flow direction, flow accumulation, stream definition, stream segmentation) in ARCGIS software using DEM model as input. We have been controlled drainages obtained by DEM with drainages of the survey of Iran topographical map in 1:25,000 scales. So that, 9 basins have been chosen for studying (Figure 3). Stream ordering method as suggested by Strahler has been employed [5].

Hypsometric describes area distribution at different elevations [5] and can be estimated using the hypsometric curve or the hypsometric integral (HI). The index is defined as the relative area below the hypsometric curve and thus expresses the volume of a basin that has not been eroded [17]. The hypsometric integral can be approximated by means of the following equation (Keller and Pinter, 2002):

$$
H I=(\text { average elevation }-\min \text {. elevation }) /(\max \text {. elevation }-\min \text {. elevation })
$$




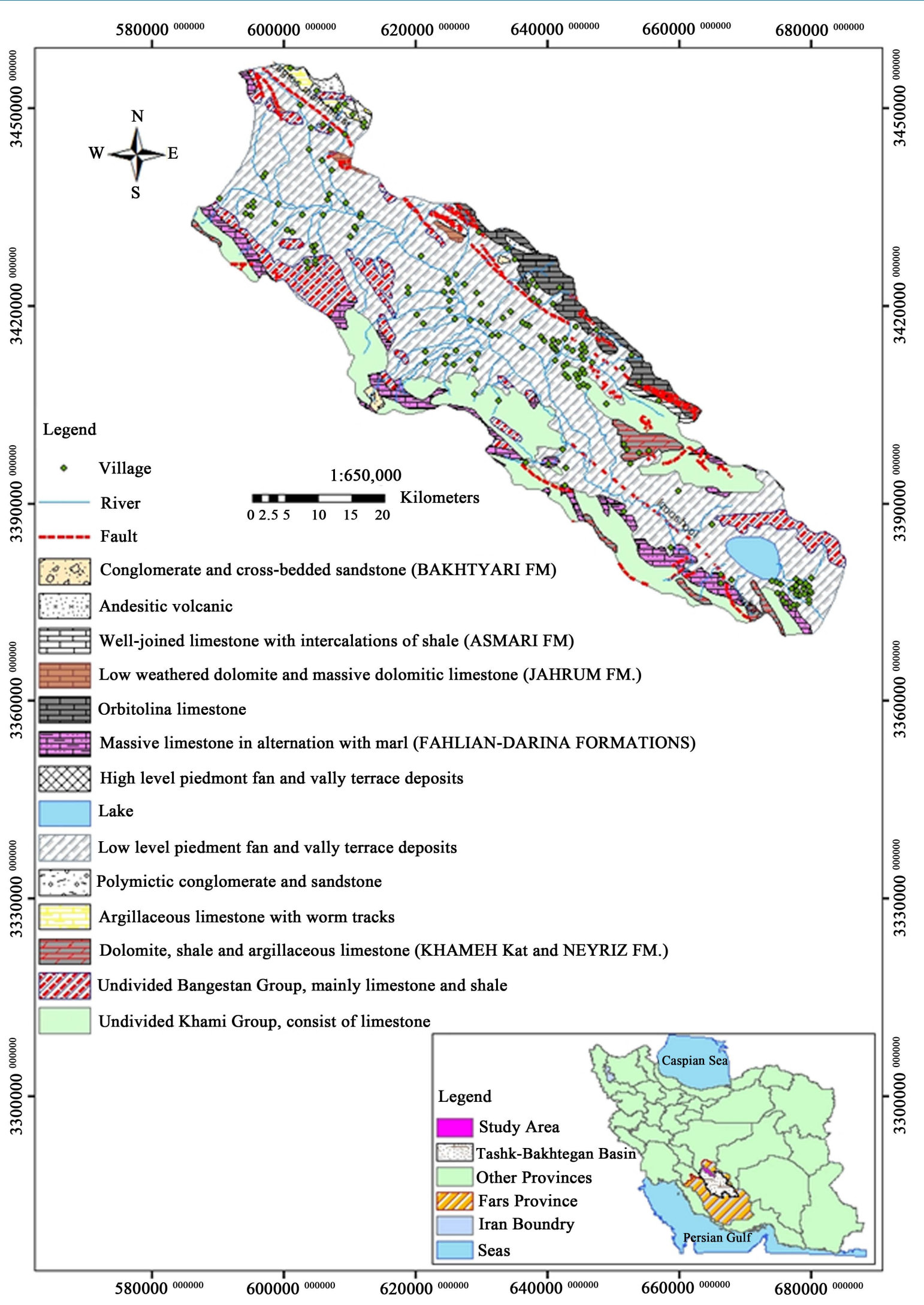

Figure 2. Geology map of Namdan basins Iran. 


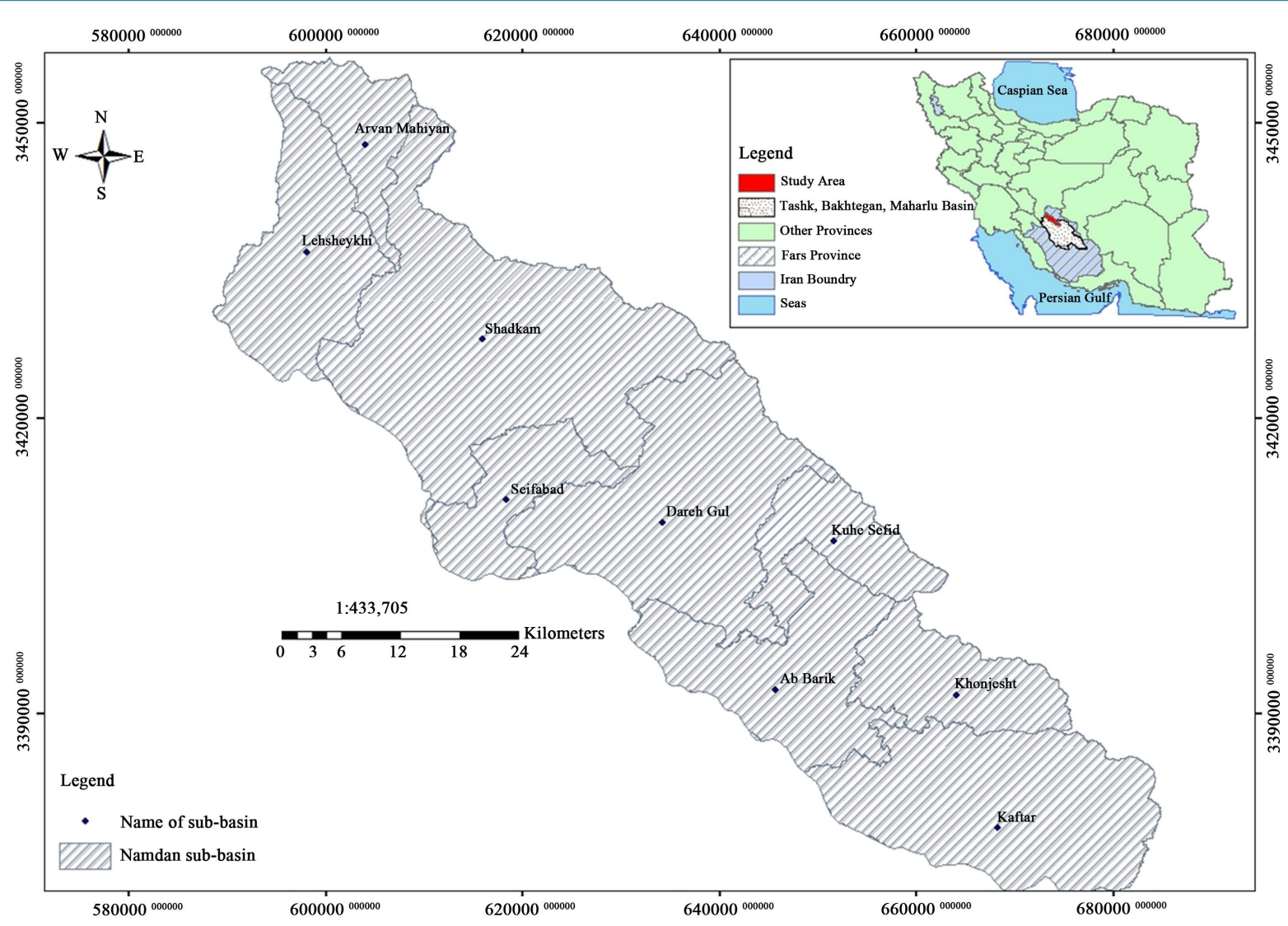

Figure 3. Determination of sub-basins in Namdan basin based on Digital Elevation Model (DEM).

The elevation value of DEM (Figure 4) has been used to find out the hypsometric integral for each basin in the Namdan basin. Programming in excel has been used to determine the hypsometric curve values. In order to generate the map of hi value, at the first, polygon shape file converted to point features by xtools pro and then the spatial analyst has been used. Finally, we classified Namdan basin based on three classifies called Strahler [5], El Hamdouni et al. [18] and Ramu and Mahalingam [6].

Strahler [5] interpreted the shapes of the hypsometric curves by analyzing numerous drainage basins and classified them as youth (convex upward curves), mature (s-shaped hypsometric curves which is concave upwards at high elevations and convex downwards at low elevations) and peneplain or distorted (concave upward curves) [19]. HI values were grouped into three classes with respect to the convexity or concavity of the hypsometric curve by El Hamdouni et al. [18]: class 1 with convex hypsometric curves (HI $\geq 0.5$ ); class2 with concaveconvex hypsometric curves $(0.4 \leq \mathrm{HI}<0.5)$; and class3 with concave hypsometric curves $(\mathrm{HI}<0.4)$. Ramu and Mahalingam [6] have been classified the HI values as following. If the result value was between 0.6 and 1; it indicates the youthful state of dissection; if the result value was between 0.3 and 0.60 , it indicates a maturely dissected landform; and if the result was less than 0.35 , then it indicates an equilibrium or old state of dissection.

\section{Results and Discussion}

The hypsometric integral value ranges from 0.18 (sub-basin Lahsheykhi) to 0.31 (sub-basin KuheSefid). The hypsometric curve and the hypsometric integral are valuable tools in characterizing topography because they are correlated with the stages of geomorphic development of the landscape [16]. The values of elevation necessary for the calculation are obtained from a Digital Elevation Model. The average elevation is from 50 points of elevation taken at random from the drainage basin. The hypsometric curve represents the relative proportion of area below (or above) a given height (Figure 5).

The total of Namdan basin is located in mature in the peneplain or distorted based on Strahler [5] (Table 1). 


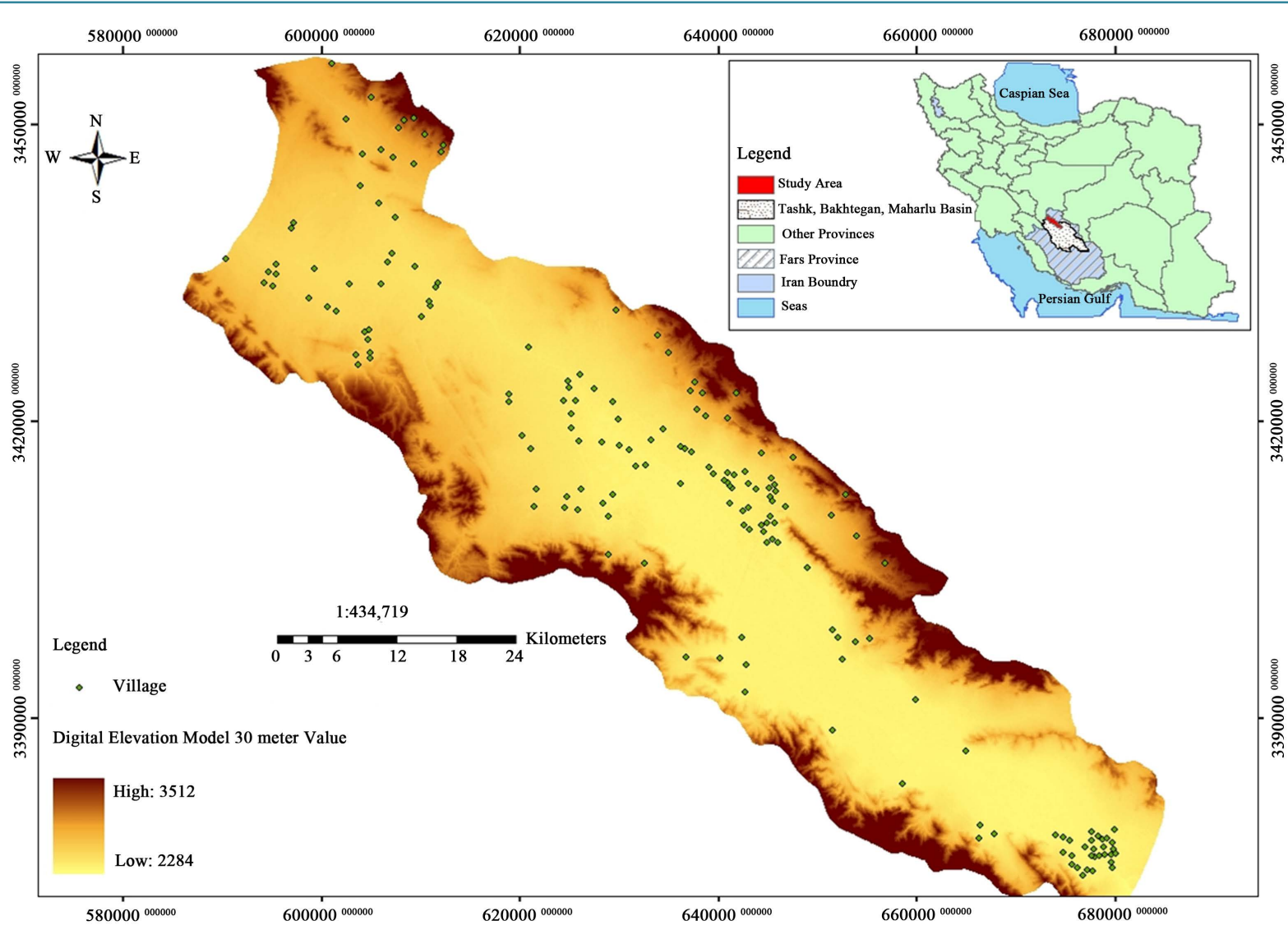

Figure 4. Digital Elevation Model of Namdan basin.

Table 1. Hypsometric integral-Namdan basin [HI (hypsometric integral value), used classification of HI is [5] [6] and [18].

\begin{tabular}{cccccc}
\hline Basin No. & Basin Name & HI & \multicolumn{3}{c}{ Classifications of HI } \\
\cline { 4 - 6 } & ArvanMahiyan & 0.21 & Strahler [5] & El Hamdouni [18] & Ramu, Mahalingam [6] \\
\hline & Lehsheykhi & 0.18 & 3 & 3 & 3 \\
3 & Shadkam & 0.25 & 3 & 3 & 3 \\
4 & Seifabad & 0.26 & 3 & 3 & 3 \\
5 & DarehGul & 0.29 & 3 & 3 & 3 \\
6 & Kuhesefid & 0.31 & 3 & 3 & 3 \\
7 & AbBarik & 0.26 & 3 & 3 & 3 \\
\hline
\end{tabular}

HI values were grouped into three classes with respect to the convexity or concavity of the hypsometric curve by El Hamdouni et al. [18] as mentioned the previous section. On based it, Namdan basin was located into class 3 (Table 1). Our area indicates old state of dissection based Ramu and Mahalingam classification [6] (Table 1).

Hypsometric integral data were derived for each of the nine drainage basins from $30 \mathrm{~m} \mathrm{DEM}$ has been indicated in Table 1. The result of the hypsometric integral shows all drainage basins come under the class 3 in all of classifications. The result of hypsometric integral values has been mapped (Figure 6). The average value of 


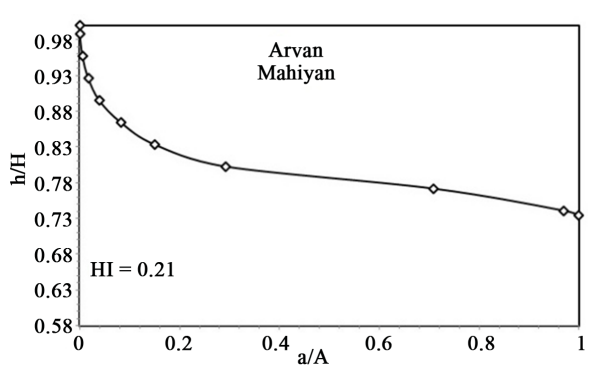

(a)

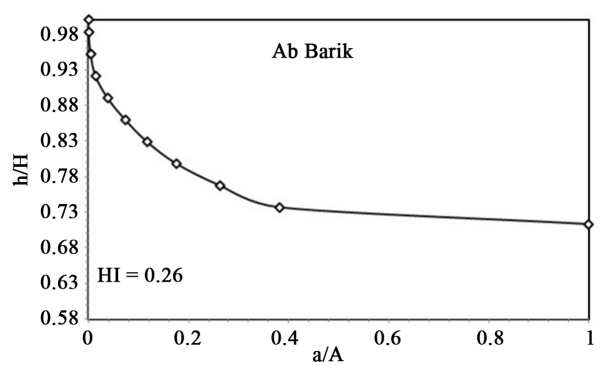

(c)

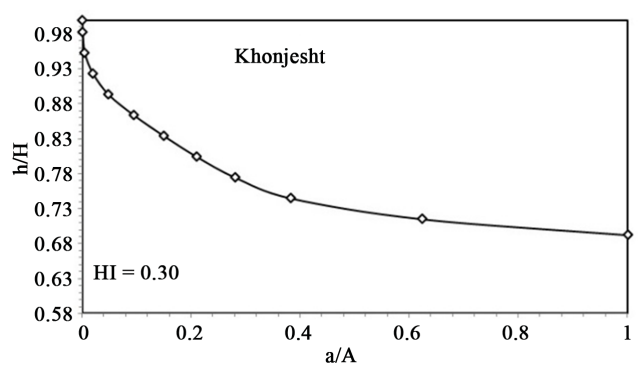

(e)

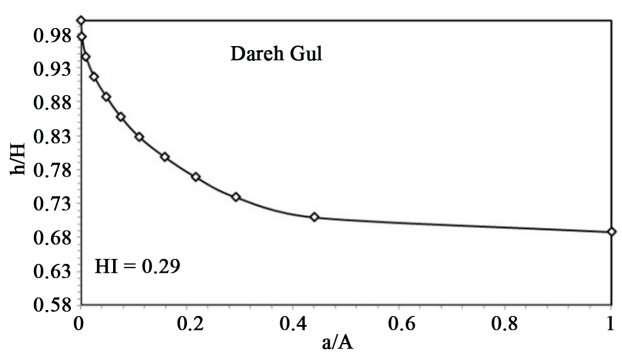

(g)

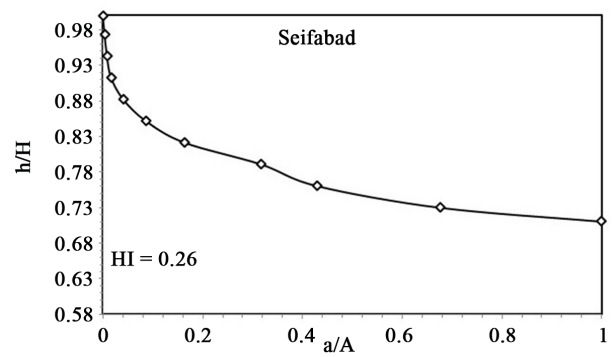

(i)

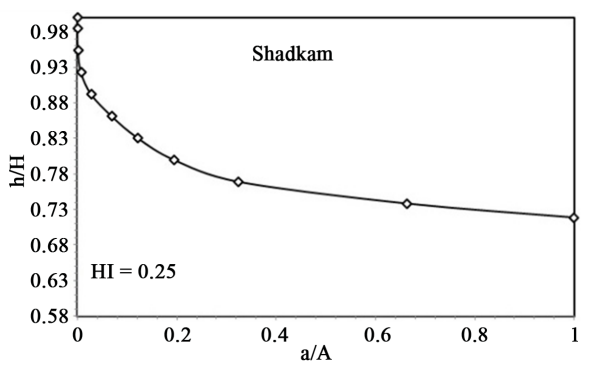

(b)

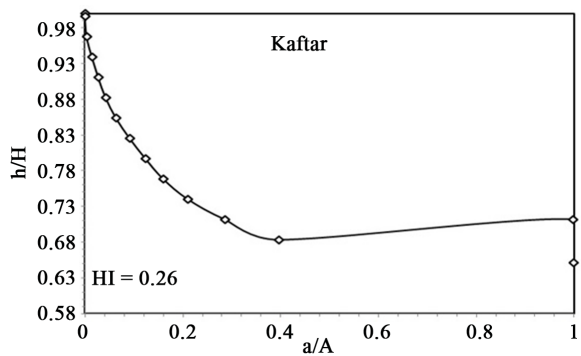

(d)

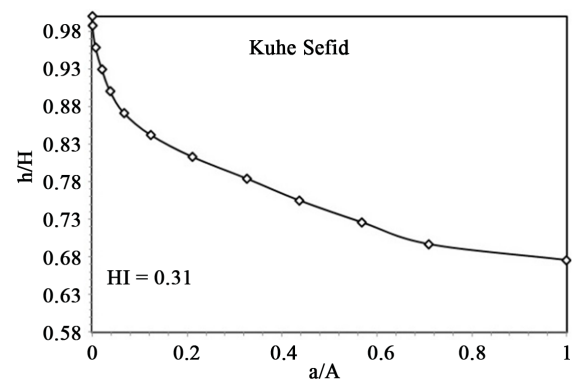

(f)

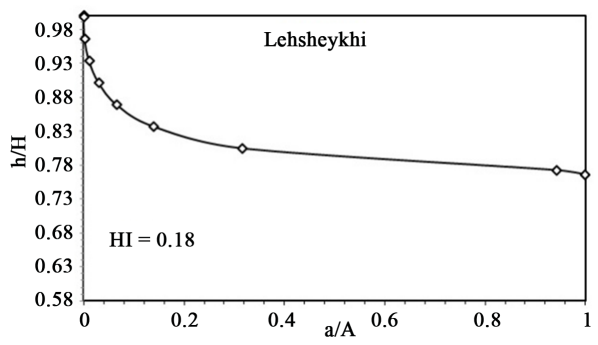

(h)

Figure 5. Hypsometric curves of basins (a) is the total surface area within the basin above a given line of elevation (h), (h) is the highest elevation of basin. 


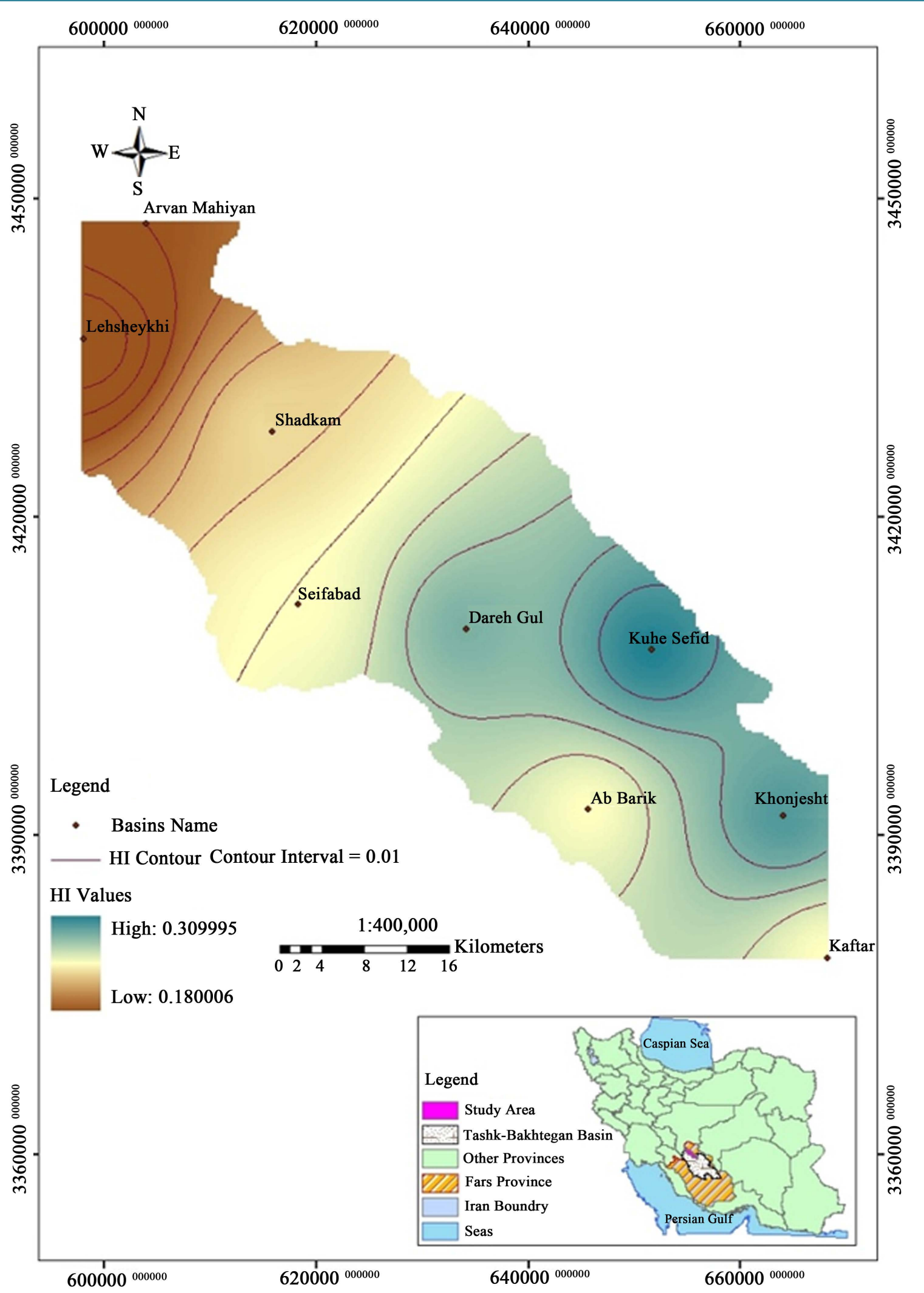

Figure 6. It shows the distribution of obtained hypsometric integral value and its contoured map at Namdan basin. Contour interval was selected 0.01 according to HI value. 
HI value is 0.258 .Then, HI value (Figure 7) was contoured (Figure 6) by spatial analyst extension and the hypsometric integral value map of Namdan basin has been used as a base map. It shows Hi changes are equal in all of parts of Namdan basin.

We compare the results in three mentioned classification and provide HI distributions maps based on them to see the visual situation of basin according them (Figure 8). In Strahler [5], El Hamdouni [18] and Ramu and Mahalingam [6] classification shows all of sub-basins located in class 3.

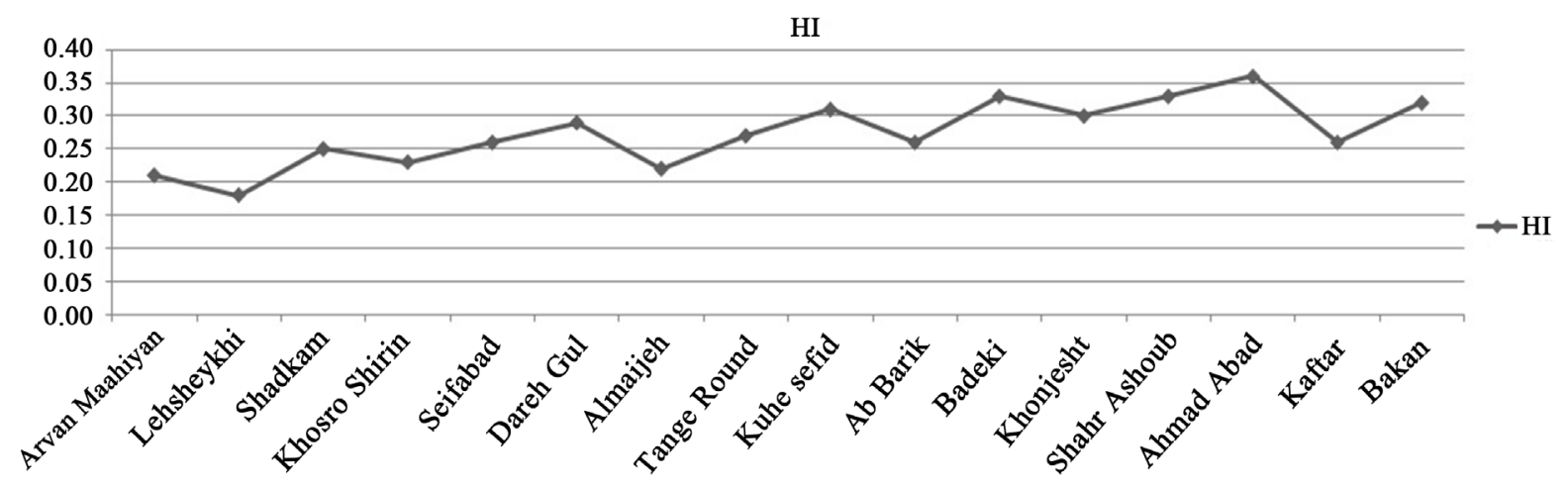

Figure 7. It shows the changes of HI value at different Namdan sub-basins.

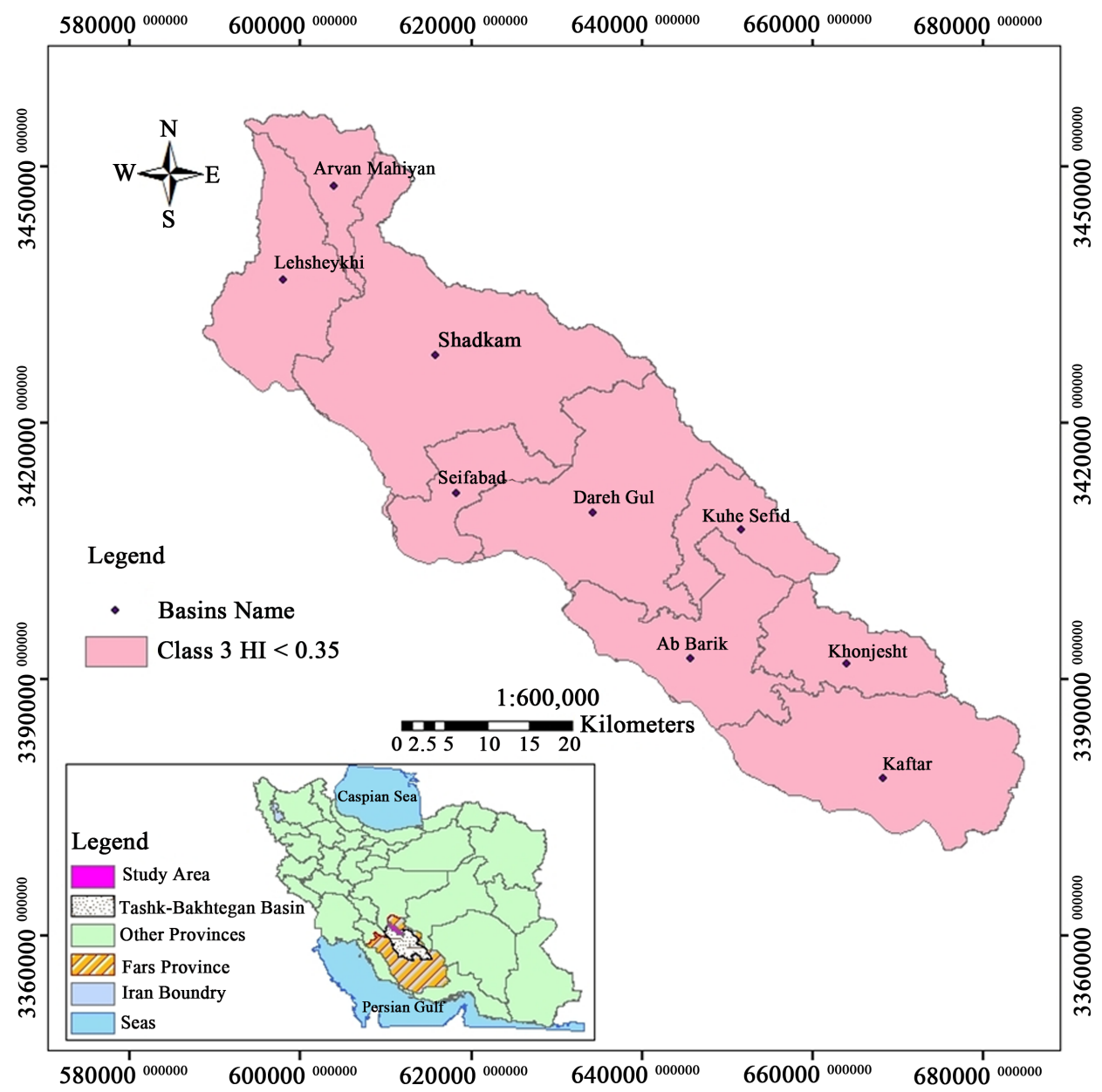

Figure 8. It shows HI combined classification map. This map is the combination of three classifications Strahler, El Hamdouni, and Ramu and Mahalingam. 
Consider to hypsometric is affected principally by tectonics, lithology, and climatic factors [1] [16] so that these factors considered in interpretation. The hypsometric curves not only have been used to infer the stage of development of the drainage network but also it is a powerful tool to identify different between tectonically active and inactive areas [2].

In this study, spatial variations of tectonic activity at Namdan basin were investigated by hypsometric integral analysis. The changes of hypsometric integral have point to a general trend of increasing tectonics activity towards the northwest.

We matched hypsometric integral value, tectonics map, lithology and climatic data (Figure 9) for distinguishing their effects. The results show that basins located at a part of northeast and southwest of Namdan basin have high values of HI. The part of northeast basin has been covered by limestone and other high strength rocks so that it has low erosion rather than other portions whereas the other portions have high erosion because of having low strength rock even southwest part except, a small part of Kaftar sub-basin. It is essential to notice Namdan basin has a same climate in all of itself why lithology less vast. So that, the role of tectonics is more than other factors in northeast portion and small part of Kaftar sub-basin (Figure 10).

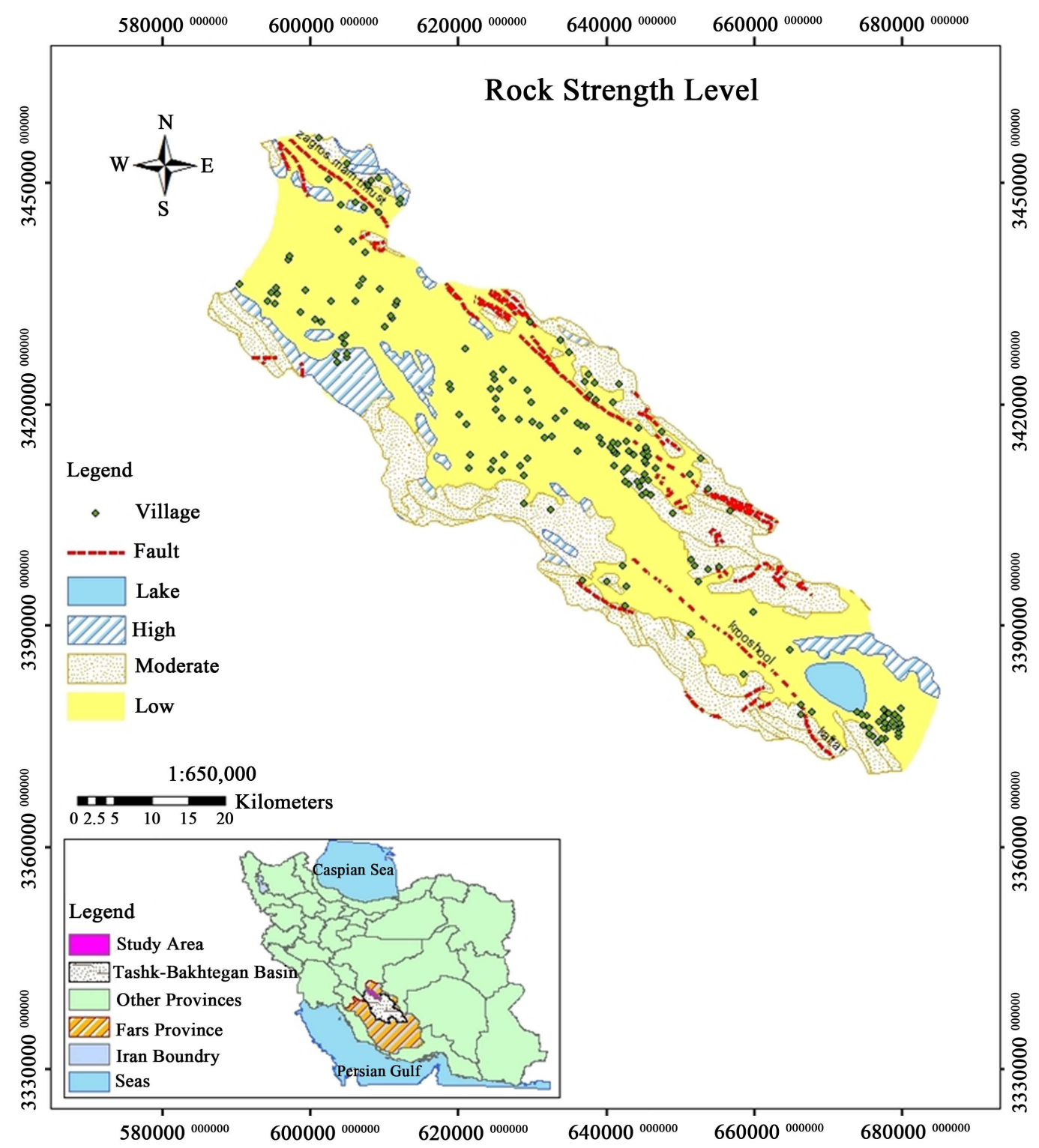

Figure 9. It shows rock strength map. 


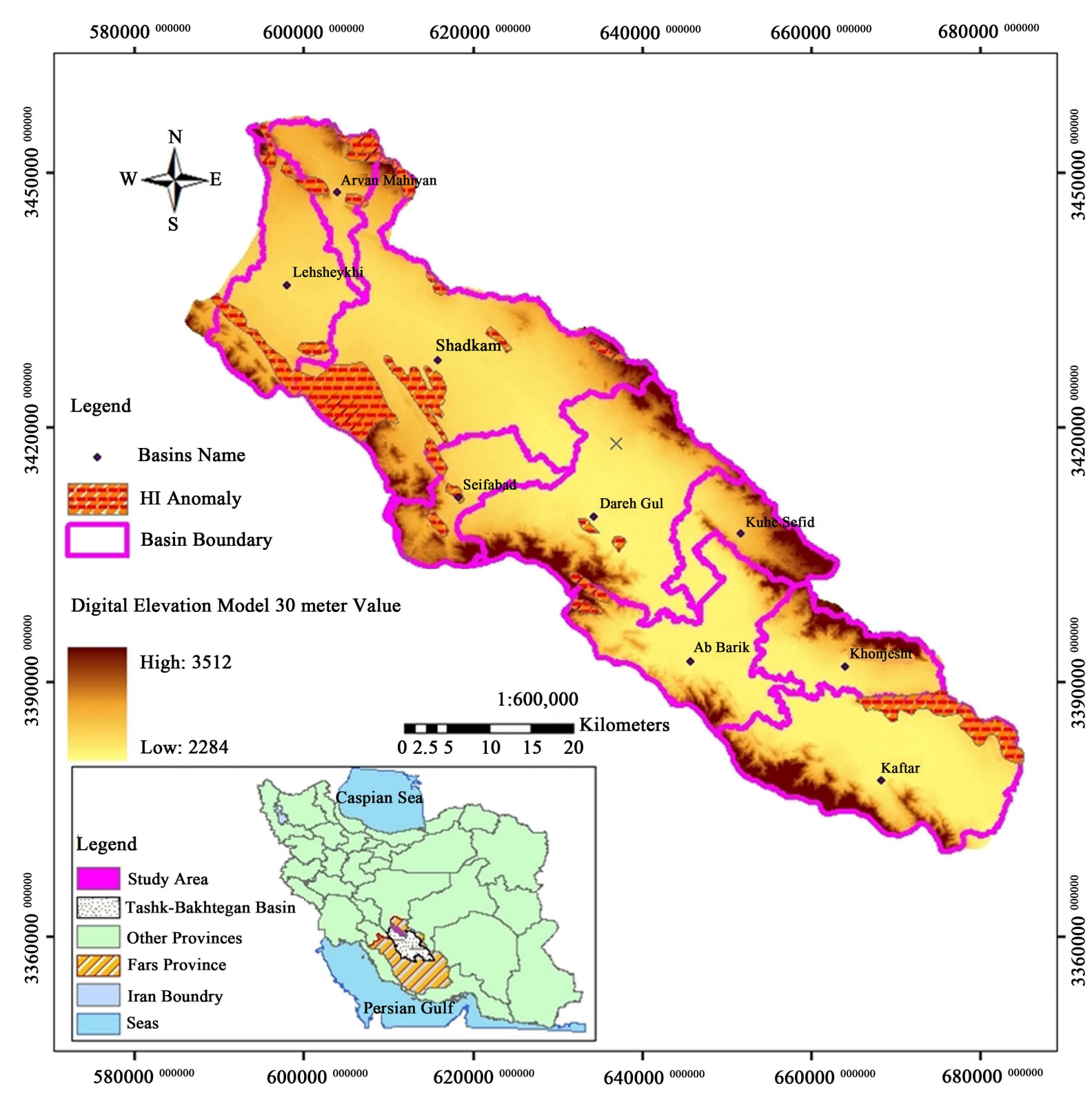

Figure 10. It shows HI changes map for the study area on DEM.

HI value distribution in lithology data is same and it doesn't differ significantly from one lithology to other one but in the strike of tectonics structures such as faults and folds variation of HI value has been happened. In fact, high hypsometric integral values indicated more tectonics activity.

In the other hand, based on the hypsometric integral values, there are in one stage of erosion cycle development, (old stage). This situation is not consist with its location on high Zagros area, because based on previous work on the salt and mud diapirism [20]-[31] and neotectonic regime in Iran [32]-[39], Zagros in south Iran is the most active zone [40]-[61]. Then, Alborz [62]-[101] and Central Iran [102]-[117] have been situated in the next orders. It seems that hydro-climatic conditions and old glacier evidence in the study area have got considerable role in this position.

\section{Conclusions}

Hypsometric integrals for the all 9 basins have been computed using GIS following Strahler [5], El Hamdouni et 
al. [18] and Ramu and Mahalingam [6] and plotted. It is considered to be suitable for evaluating these basins. The following conclusions have emerged from this study:

The study of hypsometric integral and curve has been retrieved in which the integral values vary from 0.18 to 0.31 .

The maximum hypsometric integral belongs to Kuhe Sefid sub basin.

Among the nine drainage basins, all of them are in the old state. No drainage basin comes in two other states in the study area.

The resultant hypsometric curve graphs drowned by excel has shown that s-shaped less rather than concave curve.

The value of HI was found to be high along major faults and folds.

The emphasis of the hypsometric integral on the active tectonic region in the northwest and a part of southeast of basin is completely in agreement with structures in these parts. So, these parts of Namdan basin are more active than other parts.

\section{Acknowledgements}

This work has funded by the Department of Geology, North Tehranbranch, Islamic Azad University, Tehran, Iran. Also, Special thanks to Dr. Quanbari for assistance with particular technique and for comments that greatly improved the manuscript. Finally, we appreciate the reviewers of the Open Journal of Geology for their constructive suggestions.

\section{References}

[1] Burbank, D.W. and Anderson, R.S. (2001) Tectonics Geomorphology. Blackwell, Oxford.

[2] Keller, EA. and Pinter, N. (2002) Active Tectonics: Earthquakes, Uplift, and Landscape. Prentice Hall, Upper Saddle River, 432, 239-265.

[3] Panek, T. (2004) The Use of Morphometric Parameters in Tectonics Geomorphology (on the Example of the Western Beskydy MTS). Journal of Geographia, 1, 111-126.

[4] Heibati, Z., Ghodrat, M. and Ghodrat, M. (2012) RS and GIS Utilities in Providing Geological Map.

[5] Strahler, A. (1968) Hypsometric (Area-Altitude) Analysis of Erosional Topography. Geology Society of America, 63, 1117-1142.

[6] Ramu and Mahalingam, B. (2012) Hypsometric Properties of Drainage Basins in Karanataka Using Geographical Information System. New York Science Journal, 5, 156-158.

[7] Quanbari, H., Pourkermani, M., Asadi, AM., Bouzari, S. and Ghorashi, M. (2014) Hypsometric Properties of Marvdasht Plain Basins in SW Iran (South of Zagros Fold-Thrust Belt). Current Trends in Technology and Science, 3 , 2279-0535.

[8] Mardani, Z., Ghorashi, M., Arian, M. and Khosrotehrani, K.H. (2011) Geomorphic Signatures of Active Tectonics in the TalaghanRud, Shah Rud and SefidRud Drainage Basins in Central Alborz, N Iran. Scientific Quarterly Journal, Geosciences, 78, 159-167.

[9] Berberian, M. (1976) An Explanatory Note on the First Seismotectonics Map of Iran; A Seismo-Tectonics Review of the Country. Geological survey of Iran, Report 39, 7-141.

[10] Stöcklin, J. and Nabavi, M.H. (1973) Tectonic Map of Iran 1:2,500,000. Geological Survey of Iran.

[11] Asadi, A.M., Nikoonejad, A. and Quanbari, H. (2014) Study of Guyum Fault Zone in Geodetic Approach, Zagros. Current Trends in Technology and Science, 3, 118-125.

[12] Asadi, A., Quanbari, H. and Nikoonejad, A. (2013) Strain Analysis of the Darvazeh Quran Fault, Zagros Mountains, Iran. Iranian Journal of Science \& Technology (IJST), 37, 467-475. http://ijsts.shirazu.ac.ir

[13] Arian, M. (2013) Physiographic-Tectonic Zoning of Iran’s Sedimentary Basins. Open Journal of Geology, 3, $169-177$. http://dx.doi.org/10.4236/ojg.2013.33020

[14] Islamic Republic of Iran Meteorological Organization (2011) Do Martin Climate Zoning Map.

[15] Rezaei, A., Zare, M., Raeisi, E. and Ghanbari, M. (2013) Interaction of a Freshwater Lake and a Karstic Spring via a Syncline Fold. Groundwater, 51, 305-312.

[16] Perez Pena, J.V. (2009) Gis-Based Tools and Methods for Landscape Analysis and Active Tectonics Evaluation. Master's Thesis, Departamento de Geodinamica, Universidad de Granada, Granada. 
[17] Dehbozorgi, M., Pourkermani, M., Arian, M., Matkan, A.A., Motamedi, H. and Hosseiniasl, A. (2010) Quantitative Analysis of Relative Tectonic Activity in the Sarvestan Area, Central Zagros, Iran. Geomorphology, 121, 329-341. http://dx.doi.org/10.1016/j.geomorph.2010.05.002

[18] El Hamdouni, R., Irigaray, C., Fernandez, T., Chacon, J. and Keller, E.A. (2008) Assessment of Relative Active TecTonics, Southwest Border of Sierra Nevada (Southern Spain). Geomorphology, 96, 150-173. http://dx.doi.org/10.1016/j.geomorph.2007.08.004

[19] Singh, O., Sarangi, A. and Sharma, M.C. (2008) Hypsometric Integral Estimation Methods and Its Relevance on Erosion Status of North Western Lesser Himalayan Watershed. Water Resources Management, 22, 1545-1560. http://dx.doi.org/10.1007/s11269-008-9242-z

[20] Arian, M. (2011) A Preface on Salt Diapirism of Iran. Asar Nafis Press, Qum, 309 p.

[21] Arian, M. and Noroozpour, H. (2015) The Biggest Salt-Tongue Canopy of Central Iran. Open Journal of Geology, 5, 55-60. http://dx.doi.org/10.4236/ojg.2015.52005

[22] Asadian, F., Pourkermani, M. and Arian, M. (2007) Tectonic Geomorphology of Salt Structures in the GarmsarLasjerd Area. Geographical Research, 39, 75-84.

[23] Pourkermani, M. and Arian, M. (1997) Salt Domes of Central Iran. Journal of Humanities, 3, $29-41$.

[24] Arian, M. (2012) Salt Diapirism and Tectonics. Second Edition, Asar Nafis Press, Qum, 319 p.

[25] Arian, M. and Noroozpour, H. (2015) Tectonic Geomorphology of Iran’s Salt Structures. Open Journal of Geology, 5, 61-72. http://dx.doi.org/10.4236/ojg.2015.52006

[26] Asadian, F. and Arian, M. (2009) Identification of Diapiric Provinces of Central Iran through Geological and Geographical Analysis. International Journal of Agriculture Environment \& Biotechnology, 2, 3443-3451.

[27] Arian, M. (2012) Clustering of Diapiric Provinces in the Central Iran Basin. Carbonates and Evaporites, 27, 9-18. http://dx.doi.org/10.1007/s13146-011-0079-9

[28] Pourkermani, M. and Arian, M. (1998) Tectonic Geomorphology of Salt Domes in West of Zanjan Province, Iran. Geographical Research, 47, 44-53.

[29] Arian, M. and Feizi, F. (2010) The Significance of Faulting on the Surficial Spreading of Evaporitic Deposits in the Varamin-Semnan Area. Journal of Earth and Resources, 3, 1-20.

[30] Feizi, F., Arian, M. and Arian, A. (2015) Mud Diapirism on the Makran, Iran: Case Study on the Napag Mud Volcano. Open Journal of Geology, 5, 300-308. http://dx.doi.org/10.4236/ojg.2015.55027

[31] Arian, M. and Sistanipour, A. (2015) Mud Diapirism on the Gorgan, North Iran. Open Journal of Geology, 5, $442-450$. http://dx.doi.org/10.4236/ojg.2015.56041

[32] Arian, M. and Khodabakhshnezhad, A. (2015) Sedimentary Environments Can Be Changed by Geotechnology (Case Study: A Morphotectonic Idea for Design of Extensive Artificial Bay on the Iranian Plateau). International Journal of Geosciences, 6, 487-496. http://dx.doi.org/10.4236/ijg.2015.65039

[33] Arian, M. (2011) Middle East Tectonics. Asar Nafis Press, Qum, 236 p.

[34] Arian, M. (2010) Applied Seismotectonics. Farazamin Press, Tehran, 304 p.

[35] Arian, M. and Maleki, R. (2008) Neotectonics. Farazamin Research Center, Tehran, 150.

[36] Pourkermani, M. and Arian, M. (1998) Seismicity of Iran. Shahid Beheshti University Press, Tehran, 212.

[37] Pourkermani, M. and Arian, M. (1997) Seismotectonics. DezAb Consulting Engineers Company Press, Tehran, 270.

[38] Qorashi, M. and Arian, M. (2011) Tectonics of Iran. Geologic Survey of Iran, Tehran, 336 p.

[39] Arian, M. (2011) Basement Tectonics and Geology of Iran. Asar Nafis Press, Qum, 300 p.

[40] Arian, M. and Aram, Z. (2014) Relative Tectonic Activity Classification in the Kermanshah Area, Western Iran. Solid Earth, 5, 1277-1291. http://dx.doi.org/10.5194/se-5-1277-2014

[41] Mashal, M., PourKermani, M., Charchi, A., Almasian, M. and Arian, M. (2013) Pattern of Structural Geology Underground in Eastern of North Dezfol Embayment. Advances in Environmental Biology, 7, 260-268.

[42] Pazhoohan, M., Arian, M., Ghorashi, M. and Khosrotehrani, K. (2014) A Study of Drainage Pattern Responses to Active Tectonics in Tadvan Region, SW Iran. Geodynamics, 1, 36-41.

[43] Rahimi, N. and Arian, M. (2014) Tectonic Geomorphplogy of Kangavar-Sosangerd Region, West Iran. Advances in Environmental Biology, 8, 119-124.

[44] Arian, M. and Hashemi, A. (2008) Seismotectonic Zoning in the Zagros. Journal of Sciences, 18, 63-76.

[45] Arian, M., Ahmadnia, A., Qorashi, M. and Pourkermani, M. (2002) Structural Analysis of Mengharak Transcurrent 
Fault System in Zagros, Iran. Special Geo 2002 Conference Issue Geoarabia, 7, 209-210.

[46] Arian, M., Qorashi, M., Pourkermani, M. and Ahmadnia, A. (2003) Fractal Analysis of Mengharak Transcurrent Fault System in Zagros, Iran. Proceedings of the Fourth International Conference on Seismology and Earthquake Engineering, Tehran, 12-14 May 2003, 23.

[47] Baharvand, S., Pourkermani, M., Ajalloian, R., Arian, M. and Nouryazdan, A.R. (2010) Seymareh Landslide and Its Role in Environmental and Geomorphologic Changes of the Pole-Dokhtar Area. Journal of the Earth, 4, 13-24.

[48] Abdideh, M., Qorashi, M., Rangzan, K. and Arian, M. (2011) Assessment of Relative Active Tectonics Using Morphometric Analysis: Case Study of Dez River (Southwestern, Iran). Geosciences, 20, 33-46.

[49] Arian, M., Qorashi, M., Pourkermani, M. and Ahmadnia, A. (2006) The Structural Significance Kareh Bas Transcurrent Fault System in the Zagros Fold and Thrust Belt. Geosciences, 15, 126-133.

[50] Arian, M. and Noroozpour, H. (2015) Seismic Activity and Fractal Geometry of Kareh Bas Fault System in Zagros, South of Iran. Open Journal of Geology, 5, 291-299. http://dx.doi.org/10.4236/ojg.2015.55026

[51] Ehsani, J. and Arian, M. (2015) Quantitative Analysis of Relative Tectonic Activity in the Jarahi-Hendijan Basin Area, Zagros Iran. Geosciences Journal, 19, 1-15. http://dx.doi.org/10.1007/s12303-015-0016-3

[52] Omidali, M., Arian, M. and Sorbi, A. (2015) Neotectonics of Boroujerd Area, SW Iran by Index of Active Tectonics. Open Journal of Geology, 5, 309-324. http://dx.doi.org/10.4236/ojg.2015.55028

[53] Chegini, A., Sorbi, A. and Arian, M. (2015) Active Tectonics of Hamedan Area, West Iran. International Journal of Geography and Geology, 4, 109-128.

[54] Maleki, Z., Arian, M., Solgi, A. and Ganjavian, M.A. (2014) The Elements of Fold Style Analysis in the Khaftar Anticline, Zagros, Iran. Open Journal of Geology, 4, 79-92. http://dx.doi.org/10.4236/ojg.2014.43008

[55] Maleki, Z., Arian, M. and Solgi, A. (2014) Structural Style and Hydrocarbon Trap of Karbasi Anticline, in the Interior Fars Region, Zagros, Iran. Solid Earth Discussions, 6, 2143-2167. http://dx.doi.org/10.5194/sed-6-2143-2014

[56] Ehsani, J., Arian, M. and Ghorashi, M. (2015) Geomorphic Signatures of Active Tectonics in the Jarahi-Hendijan Drainage Basin in the South West Iran. Geosciences, 24, 211-218.

[57] Khodabakhshnezhad, A., Pourkermani, M., Arian, M., Matkan, A.A. and Charchi, A. (2015) Active Tectonics of Great Karoun River Basin. Geosciences, 24, 13-28.

[58] Maleki, Z., Arian, M., Solgi, A. and Ganjavian, M.A. (2015) Elements of Fold Style Analysis in the Karbasi Anticline, Interior Fars Region, Zagros. Geosciences, 24, 293-302.

[59] Baratpour, F., Arian, M. and Solgi, A. (2015) Geometric Analysis of Tukak and Kamarun Anticlines on Izeh Zone, Zagros. Geosciences, 24, 191-200.

[60] Fard, N.G., Sorbi, A. and Arian, M. (2015) Active Tectonics of Kangavar Area, West Iran. Open Journal of Geology, 5, 422-441. http://dx.doi.org/10.4236/ojg.2015.56040

[61] Maleki, Z., Arian, M. and Solgi, A. (2015) Folding Pattern in the Fars Province, Zagros Folded Belt: Case Study on the Karbasi and Khaftar Anticlines, Interior Fars, Iran. Solid Earth Discussions, 7, 2347-2379.

[62] Alladin, Y., Talebian, M., Arian, M. and Ahmadi, M.M. (2015) Geotechnical Investigation and Seismic Zonation of Alluvial Deposits in Western Tehran. Geosciences, 24, 333-342.

[63] Taherkhani, B., Nazari, H., Pourkermani, M. and Arian, M. (2015) Geometry and Recent Kinematics of the North Qazvin Fault: Morphotectonic Approach. Geosciences, 24, 29-38.

[64] Manuchehri, H., Arian, M., Ghorashi, M., Solgi, M. and Sorbi, A. (2015) Geomorphic Signatures of Active Tectonics in the Chalus Drainage Basin in the Alborz, Iran. Geosciences, 24, 273-280.

[65] Noroozpour, H., Arian, M. and Sorbi, A. (2015) Fault Movement Potentials in the Tehran-Semnan Region (North Iran). Open Journal of Geology, 5, 281-290. http://dx.doi.org/10.4236/ojg.2015.55025

[66] Arian, M., Maleki, Z. and Noroozpour, H. (2011) Cenozoic Diastrophism and Deformational Events in the East Central Alborz. Journal of Basic and Applied Scientific Research, 1, 2394-2400.

[67] Feizi, F., Arian, A. and Rahmani, R. (2007) Seismotectonic Zoning in the Eastern Part of the Central Alborz. Journal of Sciences, 17, 151-164.

[68] Khavari, R., Arian, M. and Ghorashi, M. (2009) Neotectonics of the South Central Alborz Drainage Basin, in NW Tehran, N Iran. Journal of Applied Sciences, 9, 4115-4126. http://dx.doi.org/10.3923/jas.2009.4115.4126

[69] Arian, M. and Bagha, N. (2012) Active Tectonics of Tehran Area, Iran. Journal of Basic and Applied Scientific Research, 2, 3805-3819. 
[70] Bagha, N., Arian, M., Ghorashi, M., Pourkermani, M., El Hamdouni, R. and Solgi, A. (2014) Evaluation of Relative Tectonic Activity in the Tehran Basin, Central Alborz, Northern Iran. Geomorphology, 213, 66-87. http://dx.doi.org/10.1016/j.geomorph.2013.12.041

[71] Arian, M. and Feizi, F. (2005) Application of Geomorphic Indices to the Assessment of Relative Tectonic Activity Levels in the Alborz-Central Iran Border Zone. Journal of Sciences, 15, 378-403.

[72] Arian, M., Bagha, N., Khavari, R. and Noroozpour, H. (2012) Seismic Sources and Neo-Tectonics of Tehran Area (North Iran). Indian Journal of Science and Technology, 5, 2379-2383.

[73] Moghimi, H., Arian, M. and Sorbi, A. (2015) Fault Movement Potential of Marzanabad Area, North Alborz, Iran. Open Journal of Geology, 5, 126-135. http://dx.doi.org/10.4236/ojg.2015.53012

[74] Arian, M. and Pourkermani, M. (2004) Tectonic Elements of South Flank in the East-Central Alborz Mountain. Journal of Sciences, Teacher Training University, 4, 359-368.

[75] Arian, M. and Qorashi, M. (2006) The Movement Potential Evaluation of the Major Quaternary Faults in Alborz-Central Iran Border Zone, from the East of Tehran to the East of Semnan. Journal of Geosciences, Geological Survey of Iran, 15, 184-188.

[76] Poroohan, N., Pourkermani, M. and Arian, M. (2013) An Assessment of Relationship in F-Parameter and Paleostress Fields in Heterogeneous Lithologies: Roudbar Area (Northwest of Iran). Australian Journal of Basic \& Applied Sciences, 7, 933-942.

[77] Poroohan, N., Poukermani, M. and Arian, M. (2009) An Assessment on Correlations of Seismotectonic Parameters Preceding and Following Roudbar-Manjil Earthquake (Gilan, North of Iran). Australian Journal of Basic \& Applied Sciences, 3, 2643-2652.

[78] Farrokhnia, A.R., Pirasteh, S., Pourkermani, M. and Arian, M. (2011) Geo-Information Technology for Mass Wasting Hazard Zonation: Central-West Alborz-Iran. Disaster Advances, 4, 24-33.

[79] Khavari, R., Ghorashi, M. and Arian, M. (2009) Assessment of Relative Active Tectonics, South Central Alborz (North Iran). EGU General Assembly Conference Abstracts, 11, 1137.

[80] Sorbi, A., Arian, M. and Pourkermani, M. (2009) The Movement Potential Evaluation of the Major Quaternary Faults in Tehran Quadrangle. Journal of the Earth, 19, 176-182.

[81] Feizi, F. and Arian, M. (2006) The Classification of Thrust Fronts in the Alborz-Central Iran Border Zone from the East of Varamin to the East of Semnan. Journal of Sciences, 16, 75-87.

[82] Sadeghi, R., Saeedi, A., Arian, M., Ghorashi, M. and Solgi, A. (2015) Comparison of Strain Ellipsoid Shape in the South of Ardabil Range (NW), Based on the Results of the Magnetic Susceptibility Anisotropy and Paleostress Methods. Open Journal of Geology, 5, 611-622. http://dx.doi.org/10.4236/ojg.2015.59054

[83] Arian, M. and Pourkermani, M. (2004) Structural Significance of North Semnan and Attary Faults in Alborz-Central Iran Border Zone. Journal of Science, 14, 4551-4569.

[84] Arian, M. and Pourkermani, M. (2005) Cenozoic Diastrophism and Deformational Events in the Southern Flank of Central-East Alborz. Journal of Faculty Earth Sciences, 10, 43-51.

[85] Arian, M., Pourkermani, M., Qorashi, M. and Ghasemi, M.R. (2003) North Semnan Fault System and Its Role on Basin Division. Proceedings of the 8th Symposium of Geological Society of Iran, Shahrood, 4-6 September 2003, 11-17.

[86] Pourkermani, M. and Arian, M. (2001) Structural Geomorphology of Northeastern Kurdistan. Journal of Humanities, 7, 37-48.

[87] Mardani, Z., Ghorashi, M. and Arian, M. (2011) Geomorphic Signatures of Active Tectonics in the Talaghanrud, Shahrud and Sefidrud Drainage Basins in Central Alborz, N Iran. Geosciences, 20, 159-166.

[88] Sorbi, A., Arian, M. and Pourkermani, M. (2011) The Application of Geomorphic Indices to the Assessment of Relative Tectonic Activity Levels in Tehran Quadrangle. Journal of the Earth, 6, 1-9.

[89] Khavari, R., Ghorashi, M., Arian, M. and Khosrotehrani, K. (2010) Geomorphic Signatures of Active Tectonics in the Karaj Drainage Basin in South Central Alborz, N Iran. Geosciences, 19, 67-74.

[90] JavadiMousavi, E. and Arian, M. (2015) Tectonic Geomorphology of Atrak River, NE Iran. Open Journal of Geology, 5, 106-114. http://dx.doi.org/10.4236/ojg.2015.53010

[91] Nouri, R., Jafari, M.R., Arian, M., Feizi, F. and Afzal, P. (2013) Correlation between Cu Mineralization and Major Faults Using Multifractal Modelling in the Tarom Area (NW Iran). Geologica Carpathica, 64, 409-416. http://dx.doi.org/10.2478/geoca-2013-0028

[92] Nouri, R., Jafari, M.R., Arian, M., Feizi, F. and Afzal, P. (2013) Prospection for Copper Mineralization with Contribution of Remote Sensing, Geochemical and Mineralographical Data in Abhar 1:100,000 Sheet, NW Iran. Archives of 
Mining Sciences, 58, 1071-1084.

http://dx.doi.org/10.2478/amsc-2013-0074

[93] Nouri, R., Afzal, P., Arian, M., Jafari, M. and Feizi, F. (2013) Reconnaissance of Copper and Gold Mineralization Using Analytical Hierarchy Process in the Rudbar 1: 100,000 Map Sheet, Northwest Iran. Journal of Mining and Metallurgy, 49, 9-19.

[94] Farrokhnia, A.R., Pirasteh, S., Pradhan, B., Pourkermani, M. and Arian, M. (2011) A Recent Scenario of Mass Wasting and Its Impact on the Transportation in Alborz Mountains, Iran Using Geo-Information Technology. Arabian Journal of Geosciences, 4, 1337-1349. http://dx.doi.org/10.1007/s12517-010-0238-7

[95] Arian, M. and Nouri, R. (2015) Lineament Tectonics and Mineralization in Tarom Area, North Iran. Open Journal of Geology, 5, 115-124. http://dx.doi.org/10.4236/ojg.2015.53011

[96] Feizi, F. and Arian, M. (2011) The Role of Structural Controllers in Geneses of Copper Deposits in 1:50000 Map of Saiin Qaleh. Journal of Sciences, 21, 1-10.

[97] Arian, M., Qorashi, M. and Ahmadnia, A. (2003) Analysis of Behbahan Shear Zone. Iranian Journal of Geology, 1, $1-4$.

[98] Bahiraee, S., Arian, M., Qorashi, M. and Solgi, M. (2015) The Movement Potential Evaluation of the Mosha Fault ( the West of Firoozkuh to the Shahrestanak). Geosciences, 24, 123-126.

[99] Bagha, N., Ghorashi, M., Arian, M., Pourkermani, M. and Solgi, A. (2015) Neotectonic Analysis of Mosha-North Tehran Fault Zone, Based on Morphotectonic Features, Central Alborz, Northern Iran. Geosciences, 24, 41-52.

[100] Mosavi, E. and Arian, M. (2015) Neotectonics of KashafRud River, NE Iran by Modified Index of Active Tectonics (MIAT). International Journal of Geosciences, 6, 776-794. http://dx.doi.org/10.4236/ijg.2015.67063

[101] Nouri, R. and Arian, M. (2015) Structural Control on the Distribution of Hydrothermal Alteration Zones and Mineralization in Dastjerdeh Area Based on Remote Sensing Data, NW Iran. Bulletin of the Georgian National Academy of Sciences, 9, 79-86.

[102] Sistanipour, A. and Arian, M. (2015) Geometric Analysis of Davaran Fault System, Central Iran. Open Journal of Geology, 5, 458-469. http://dx.doi.org/10.4236/ojg.2015.56043

[103] Nazemi, M., Ghorashi, M., Ghassemi, M.R. and Arian, M. (2015) Morphotectonics Features of Alluvial Fans Associated with Active Tectonics (Shotori Mountains, East of Tabas-Central Iran). Geosciences, 24, 91-100.

[104] Alizadeh, H. and Arian, M. (2015) Rule of Structural Factors in Formation of Porphyry Copper Deposits in South Western Part of Kerman Area, Iran. Open Journal of Geology, 5, 489-498. http://dx.doi.org/10.4236/ojg.2015.57045

[105] Mosavi, E.J. and Arian, M. (2015) Neotectonics of Tabas Area, Central Iran by Index of Active Tectonics (IAT). Open Journal of Geology, 5, 209-223. http://dx.doi.org/10.4236/ojg.2015.54019

[106] Daryani, N.J., Arian, M. and Omran, N.R. (2015) Tectonics and Mineralization of Copper in the Ardestan-Kahang Area, Central Iran by Remote Sensing. Open Journal of Geology, 5, 188-196. http://dx.doi.org/10.4236/ojg.2015.54017

[107] Arian, M. and Pourkermani, M. (2001) Rivers Morphology and Active Tectonic (Reviewing the Current Status of Ghezel Ozon River in the Province of Zanjan. Proceedings of the 5th Conference of Geological Society of Iran, Tehran, 28-30 August 2001, 556.

[108] Eshghi, Z., Arian, M. and Pourkermani, M. (2012) Structural Investigation on the Lak Mining Area (Bueen Zahra) Based on Remote Sensing, Used for Its Mineralization. Journal of the Earth, 6, 145-155.

[109] Arian, M., Toudeshki, V.H. and Noroozpour, H. (2011) Active Tectonics of Qezel Ozan River Basin, NW Iran. Journal of Applied Environmental and Biological Sciences, 1, 291-295.

[110] Alizadeh, H., Arian, M., Lotfi, M., Ghorashi, M. and Ghorbani, M. (2015) Determination of Porphyry Copper Deposit Locations Using Photo Lineament Factor in Northern Parts of the Dehaj-Sardoiyeh Belt. Geosciences, 24, $247-252$.

[111] Toudeshki, V.H., Pourkermani, M., Arian, M. and Khosrotehrani, K.H. (2011) Influence of Structures on the Ghezel Ozan River. Geosciences, 21, 55-60.

[112] Toudeshki, V.H. and Arian, M. (2011) Morphotectonic Analysis in the Ghezel Ozan River Basin, NW Iran. Journal of Geography and Geology, 3, 258-260. http://dx.doi.org/10.5539/jgg.v3n1p258

[113] Arian, M. (2015) Seismotectonic-Geologic Hazards Zoning of Iran. Earth Sciences Research Journal, 19, 7-13. http://dx.doi.org/10.15446/esrj.v19n1.40664

[114] Arian, M., Pourkermani, M., Sistanipour, A. and Noroozpour, H. (2011) Kinematic Significance of Fold- and Fault- 
Related Fracture Systems in the Rafsanjan’s Northeast Highlands (Central Iran). Journal of Basic and Applied Scientific Research, 1, 3398-3406.

[115] Arian, M., Pourkermani, M., Sistanipour, A. and Noroozpour, H. (2011) Seismicity and Fault Segmentation of BafqBaghin Fault System (Central Iran). Journal of Applied Environmental and Biological Sciences, 1, 382-396.

[116] Mosavi, E.J., Arian, M., Ghorashi, M. and Nazemi, M. (2012) Measurements of Geomorphic Indices in Tabas Area. Journal of the Earth, 7, 213-225.

[117] Arian, M. (2010) Earthquake-Fault Hazard Investigations in the Kerman Quadrangle. Journal of Sciences, 19, $176-182$. 